\title{
Manufacture of a Home-Made Spot Welding Machine from Household Electronic Waste
}

\author{
Tamás BÍRÓ, ${ }^{1}$ József Bálint RENKÓ ${ }^{2}$ \\ ${ }^{1}$ Budapest University of Technology and Economics, Department of Materials Science and Engineering, \\ Budapest, Hungary, biro.tamas@edu.bme.hu \\ ${ }^{2}$ Budapest University of Technology and Economics, Department of Materials Science and Engineering, \\ Budapest, Hungary, renko.jozsef@edu.bme.hu
}

\begin{abstract}
Nowadays, spot-welding technologies are being used on a very wide range of applications. Spot-welded joints can be found in many pieces of equipment, such as toasters, computers, telephone batteries, or even in various pre-manufactured car elements. Given the prevalence of the technology, there may be a legitimate need for a machine that can be used at home for simple spot-welding operations. Such a device could be produced more cost-effectively than those currently available on the market, while using household electronic waste. These could be produced for hobby purposes, thus creating an opportunity to recycle certain types of household electronic waste, thereby improving sustainability in an engineering approach.
\end{abstract}

Keywords: spot welding, battery, sustainability.

\section{Introduction}

Continuously increasing consumer demand is a major challenge for industry. The limited resources available encourage engineers to create new, sustainable technologies and to upgrade existing ones. Welding has undergone continuous development since the 20th century [1-3]. Nowadays, arc welding machines can be found not only in industrial sectors, but also in many household workshops. However, this cannot be said about resistance welding machines due to the price of these devices [4]. The inspiration of this paper was the idea of creating a hobby spot welding machine, which could be brought to life to solve a practical problem. The repair of a damaged battery of a household drill is typically made by a spot-welding operation. The basic idea was given by a blog post [5] in which the transformer of a microwave oven was used for similar purposes. We wanted to further develop this concept by creating a spot-welding machine mostly made of recycled parts, and which could later become a marketable product for hobby purposes.

\section{Design and manufacture}

At first, the establishment of a detailed list of requirements was assembled, considering the characteristics of existing equipment [6-8]. Examples of such requirements include (but are not limited to) $230 \mathrm{~V}$ for mains operation, IP 33 protection, simple design, mobility and environmental considerations. Welding time and current should be controllable. Henceforth, the structure was required to be able to form overlapping joints between $0.1-0.15 \mathrm{~mm}$ plates. In the following, the design and manufacture of the most important parts of our machine will be described.

\subsection{Transformer}

The most expensive component of a welding machine is the transformer, which provides the low voltage and high amperage required for the operation. That was obtained from a defective microwave oven. These transformers have a higher power density than their conventional plate-mounted counterparts due to their better magnetic properties, thus providing the current required for welding in a weight- and space-sav- 
ing manner. After removing the original secondary coil of the disassembled transformer, a new, secondary coil with two rolls was formed with the largest possible wire cross-section. The modified transformer is shown in Figure 1.

\subsection{Control unit}

Although the equipment was primarily designed to meet hobby needs, especially spot welding of battery cells to one another, it is still very important to control the welding process properly. To ensure the adjustability of the welding current and the welding time, a control circuit was designed $[9,10]$. The current applied during welding works on the principle of phase splitting [11, 12], and the change of the welding time is realized by means of an integrated timing circuit [13].

The control panel shown in Figure 2 was made by laminating the electric circuits onto a board that was later chemical etched. At the end of the manufacturing process, the electric components were installed by soldering.

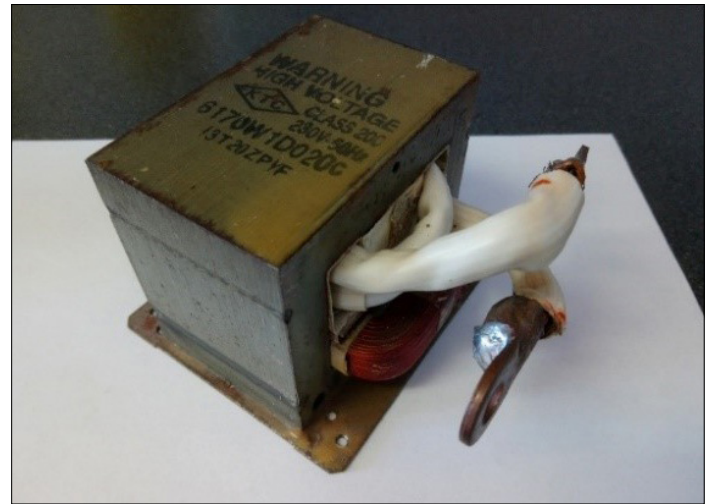

Figure 1. Modified transformer with the new secondary coil.

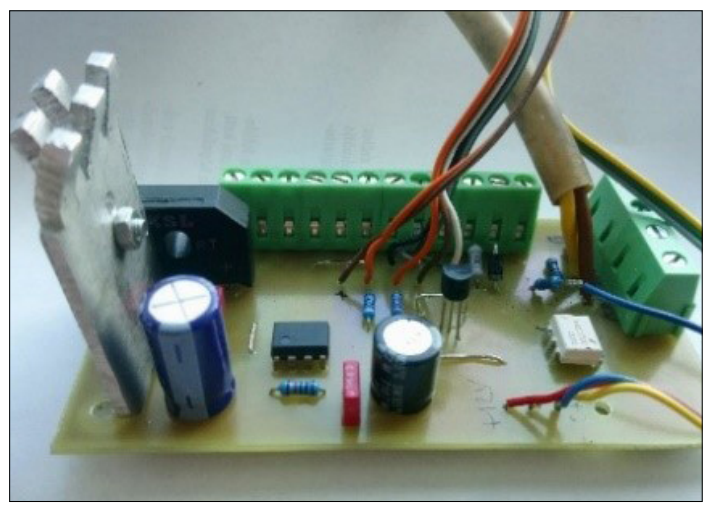

Figure 2. The control unit.

\subsection{Cladding elements and peripherals}

In order to use the equipment safely, an ergonomic machine housing and safety accessories had to be designed. The plates used for the cover were also recycled from an old refrigerator. The machine includes a footswitch which turns on and off the machine without using hands. The electrode holders were given an additional rubber cover to protect against electric shock. The electrode pressure required for welding was manually provided by pressing the electrodes on the surface of the overlapping plate parts. The completed spot welder is shown in Figure 3.

\section{Testing and quality control}

Testing is a very important aspect of product development. The requirements always had to be checked to see that they were fulfilled. To test a spot-welding machine the welded joints it produces must be examined. There are several methods for testing spot welded joints [14], of which shear-tensile testing has been performed to qualify spot welds.

The specimens were formed by overlapping S235JR steel plates of $0.1 \mathrm{~mm}, 0.2 \mathrm{~mm}$, and $0.3 \mathrm{~mm}$ thickness. The welding times were set to $0.5 \mathrm{~s}, 1 \mathrm{~s}$ and $3 \mathrm{~s}$, while the maximum current of the equipment was used. From the plate thickness - welding time pairs thus determined, 10 - 10 test welds were performed as shown in Figure 4. When placing the spot welds, care must be taken to minimize unwanted torsional stresses and their effects [9].

Qualification was performed qualitatively by macroscopic examination of the rupture site of the specimens. The tensile test was performed at a rate of $2 \mathrm{~mm} / \mathrm{min}$. Based on these, the equip-

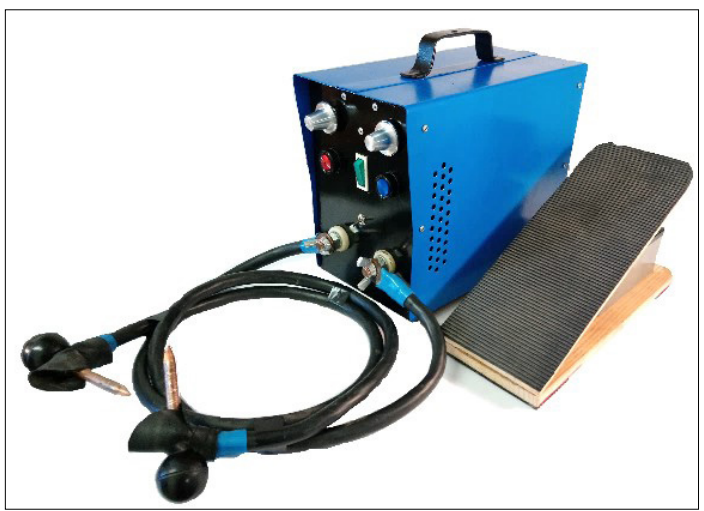

Figure 3. The finished spot-welding machine with work, electrodes, and foot switch. 


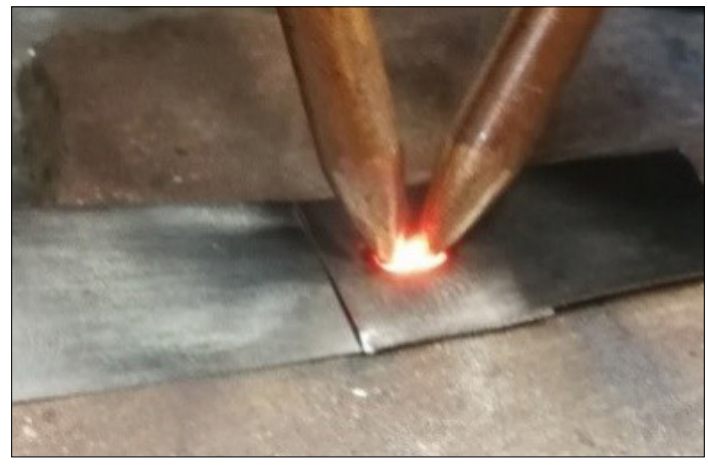

Figure 4. Spot welding of test specimens for shear-tensile testing.

ment successfully welded the $0.1 \mathrm{~mm}$ plates in $88 \%$, the $0.2 \mathrm{~mm}$ plates in $77 \%$, and the $0.3 \mathrm{~mm}$ plates in $0 \%$, excluding specimens, where the entire cross-section of the plates could not melt. The condition for the suitability of the welding was that the spot welds were torn from the base material under the effect of the load (Figure 5).

The next stage of testing was to create joints capable of connecting battery parts. Most batteries in machines and laptops are made from battery cells, they are installed in the form of battery packs, which in $99.97 \%$ of the cases are connected to one another with pure nickel tapes.

Using the created spot-welding machine, I battery packs consisting of $\mathrm{Ni}-\mathrm{Cd}$ and Li-ion cells were successfully created without cell failure [15]. Thus, the problem that gave rise to the basic idea was successfully solved (Figure 6).

\section{Conclusions}

There are many opportunities to recycle often hazardous electronic waste generated by households in cases where it has been properly collected and disposed of. The spot welder presented here is a possible solution for this. It should be emphasized, however, that without proper professional knowledge and tools, construction can be cumbersome or even dangerous. The created device is suitable for connecting battery cells with spot-welded joints between overlapping steel plates up to $0.2 \mathrm{~mm}$. Although the cost of manufacturing this machine was minimal compared to a similar piece of equipment available commercially, due to the recycled parts, other costs may be incurred at industrial production levels. During the design process we tried to ensure maintainability in a modern way.

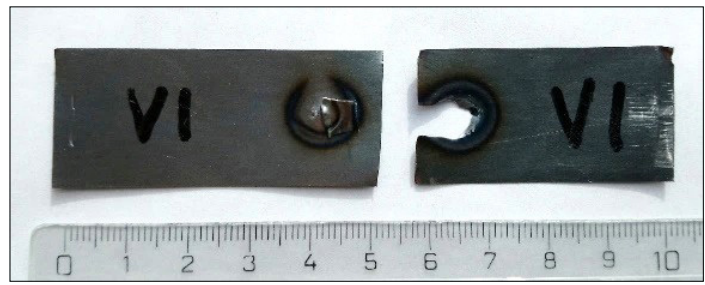

Figure 5. Aroken $0.2 \mathrm{~mm}$ thick specimen after testing.

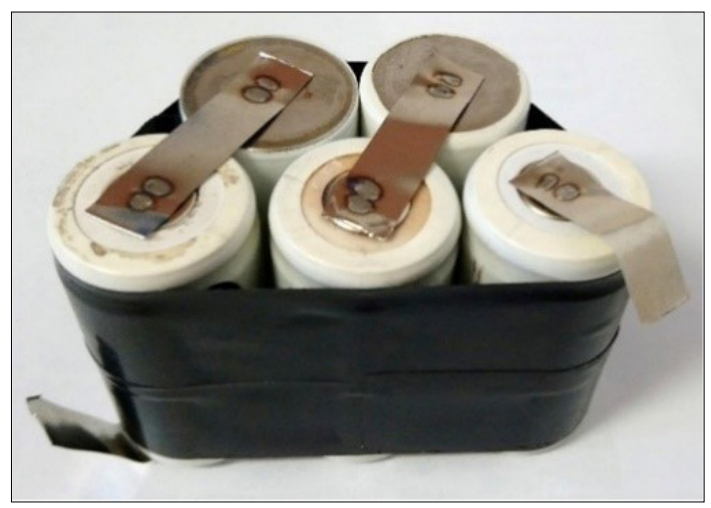

Figure 6. Ni-Cd battery pack bonded with the presented spot-welding machine.

\section{Acknowledgement}

The publication of the work reported herein has been supported by the NTP-SZKOLL-20-0067 National Talent Programme of the Ministry of Human Capacities.

\section{References}

[1] Schuler V., Twrdek J.: Praxiswissen Schweißtechnik. 6. Auflage. Springer Vieweg, Wiesbaden, 2019. 98-129.

[2] Artinger I., Kator L., Romvári P.: Fémek technológiája. 3. kiadás. Müszaki Könyvkiadó, Budapest, 1975. 306-393.

[3] Singh N. K., Vijayakumar Y.: Application of Taguchi method for optimization of resistance spot welding of austenitic stainless steel AISI 301L. Innovative Systems Design and Engineering, 3/10. (2012) 49-61.

[4] Hegesztéscentrum, Ponthegesztő gépek. 2019. https://hegesztescentrum.hu/ponthegeszto-gepek. html (accessed on: 2019. 10. 12.).

[5] Instructables workshop, MOT Spot Welder. 2013. https://www.instructables.com/id/MOT-SpotWelder-1/ (letöltve: 2019. 06. 14.).

[6] Payen G. R., Klöcker H., Lens A., Wilkinson D. S., Embury J. D.: Design of an in situ mechanical test for spotwelded joints, Engineering Fracture Mechanics, 96/12. (2013) 528-538.

https://doi.org/10.1016/j.engfracmech.2012.09.002 
[7] Han L., Thornton M., Boomer D., Shergold M.: A correlation study of mechanical strength of resistance spot welding of AA5754 aluminium alloy, Journal of Materials Processing Technology, 211/3. (2011) 513-521.

https://doi.org/10.1016/j.jmatprotec.2010.11.004

[8] Jou M.: Experimental Investigation of Resistance Spot Welding for Sheet Metals Used in Automotive Industry. JSME Int. Journal Series C Mechanical Systems, Machine Elements and Manufacturing, 44/2. (2001) 544-552.

https://doi.org/10.1299/jsmec.44.544

[9] Baránszky J. I.: Hegesztési kézikönyv. 1. kiadás. Müszaki Könyvkiadó, Budapest, 1985. 474-515.

[10] Habib Lebbal, Ahmed Reffas S., Habib Berrekia, Guagliano M.: Experimental Study of Spot Weld Parameters in Resistance Spot Welding Process. Mechanics and Mechanical Engineering, 22/1. (2020) 179-186.

https://doi.org/10.2478/mme-2018-0016
[11] Békei F., Stefanik P.: A rádiótechnika évkönyve 2004. 1. Ed., Rádióvilág Kft., Budapest, 2004. 179-196.

[12] Békei F., Stefanik P.: A rádiótechnika évkönyve 2005. 1. Ed., Rádióvilág Kft., Budapest, 2005. 196-207.

[13] Hainzmann J.: Elektronikus áramkörök. 3. kiadás. Tankönyvkiadó, Budapest, 2000. 450-453.

[14] MSZ EN ISO 14273:2002: Ellenállás-ponthegesztéssel, -vonalhegesztéssel és zömítö ellenállás-dudorhegesztéssel készített varratok nyíróvizsgálata és a próbatest méretei. 2002.

[15] Brand M., Keil P., Grubwinkler S., Jossen A., Lienkamp M.: Entwicklung und Diskussion einer 12V-Pufferbatterie aus LiFePo4-Akkumulatoren. 19. Design\&Elektronik-Entwicklerforum Batterien \& Ladekonzepte, München, 2012. 